\title{
Musik sebagai Media Dakwah
}

\author{
Tanty Sri Wulandari ${ }^{*}$, Muklish Aliyudin $1^{1}, \&$ Ratna Dewi ${ }^{2}$ \\ ${ }^{1}$ Jurusan Komunikasi Penyiaran Islam, Fakultas Dakwah dan Komunikasi, UIN Sunan Gunung \\ Djati, Bandung \\ 2Jurusan Pengembangan Masyarakat Islam, Fakultas Dakwah dan Komunikasi, UIN Sunan \\ Gunung Djati, Bandung \\ *Email : Tantysriw@gmail.com
}

\begin{abstract}
ABSTRAK
Tulisan ini bertujuan untuk mengetahui bagaimana pandangan Muhammadiyah terhadap music, bagaimana pesan dakwah yang terkandung dalam lagu Sabyan Gambus dan bagaimana pandangan Organisasi Otonom Muhammadiyah "IMM" mengenai lagu-lagu bertema Islam dari Sabyan Gambus. Metode penelitian menggunakan metode pendekatan deskriptif bersifat kualitatif, Dalam metode deskriptif menjelaskan dengan mendetail fakta yang didapat dari lapangan tentang pandangan dari "IMM" mengenai music secara umum, khususnya tentang music sebagai media dakwah. Hasil penelitian menunjukan bahwa pandagan Muhammadiyah terhadap music adalah hal yang diperbolehkan tergantung bagaimana penggunaannya begitupun dengan media music yang diperbolehkan untuk berdakwah. Dalam lagu Sabyan Gambus terdapat pesan Akidah sebanyak 25\% pada lagu yang berjudul Ya Maulana, pesan Ahlak sebanyak $50 \%$ pada lagu yang berjudul El Oum dan Syukronlillah serta pesan Syariah sebanyak $25 \%$ pada lagu yang berjudul Allahumalabaikh. Pandangan Muhammadiyah terutama IMM terhadap Sabyan Gambus kebanyakan menyetujui cara mereka berdakwah lewat media music, tidak sebagai hiburan semata tapi juga sebagai aktifitas berdakwah.
\end{abstract}

Kata Kunci : Musik; Media Dakwah; Pandangan Muhammadiyah; Organisasi Otonom Muhammadiyah "IMM"

\section{ABSTRACK}

This paper aims to find out how Mubammadiyah views on music, how the preaching massages contained in the song Sabyan Gambus an how the Mubammadiyah Autonomous Organization's "IMM" views about Islamic-themed songs from Sabyan Gambus. The research method uses descriptive qualitative approach, the descriptive method explains in detail the fact obtained from the field about the view of "IMM" about music in general, specifically 
about music as a propaganda media. The result showed that Mubammadiayah's view of music is permissible depending on how it is used as the music media that is allowed to preach. In the Sabyan Gambus song, there is a 25\% massage in the song entitled Ya Maulana, a 50\% Ablak massage in a song called El Oum and Syukronlillah an a Sharia massage a much as $25 \%$ in a song called Allabumalabaikh. Muhammadiyah's views especially IMM toward Sabyan Gambus mostly agreed on the way preached through music media, not only as entertainment but also as preaching activities.

Keywords: Music, Da'wah Media, Muhammadiyah's views, Muhammadiyah's "IMM" Autonomuos Organization

\section{PENDAHULUAN}

Kegiatan dakwah saat ini tidak hanya dilakukan dari mimbar ke mimbar namun dapat juga dilakukan dengan media-media lainnya seperti melalui tulisan film dan pagelaran-pagelaran lainnya. Salah satunya adalah dengan berdakwah melalui music. Ada beberapa diantara musisi-musisi Indonesia dan bahkan para pegiat dakwah yang ikut serta menjadikan music sebagai media untuk berdakwah, contohnya adalah Sabyan Gambus. Sabyan Gambus adalah sekelompok anak muda yang menjadikan music Islami sebagai ciri khas dari music mereka. Hadirnya Sabyan Gambus pada pertengahan tahun 2018 didalam belantika music tanah air telah memberi warna tersendiri untuk ragam music yang ada di Indonesia. Konsisten membawakan lagu-lagu bernuansa Islami telah membuat mereka dikenal oleh masyarakat luas, dan juga telah membuktikan bahwa dakwah bisa dilakukan dengan bermacam-macam media, seperti halnya berdakwah dengan menggunakan media music.

Musik merupakan suatu hal yang berpengaruh bagi kehidupan manusia baik secara positive atau negative. Kedua penagruh tersebut ditentukan oleh bagaimana kita menyikapi music yang kita rasakan, dan kita dengarkan seharihari (Grimonia, 2014; 15). Menurut beberapa tokoh seperti Plato, Aristoteles, Imam Ghozali bahkan Maulana Jalaludin Rumi musik berpengaruh terhadap kehidupab jiwa seseorang, bila musik itu berisikan hal-hal yang baik maka jiwanya akan menyerap hal baik itu, demikianpun sebaliknya. Music dapat memberi gairah dalam hidup beragama dan mendekatkan diri kepada sang Khaliq.

Music merupakan bahasa yang universal yang menjadi media komunikasi antarmasyarakat berbeda budaya

Dalam buku yang ditulis oleh Acep Aripudin menerangkan bahwa "berdakwah dengan menggunakan media kesenian termasuk seni music merupakan kebutuhan yang sangat mendesak saat ini sebab dakwah dengan 
media music selain bermakna sebagai amar ma'ruf nahi munkar, juga adalam rangka membangun intuisi umat. Apabila dakwah menggunakan media music semakin popular, maka keuntungan nya bukan hanya sebatas beramar ma'ruf nahi munkar, melainkan juga sebagai aktifitas olah rasa atau olah kalbu nantinya menghasilkan kepekaan dan kualitas hati nurani”' (Aripudin, Acep. 2012)

Salah satu organisasi keagamaan yang terbuka pada fenomena dan mengikuti arus zaman adalah Muhammadiyah. Tiga bidang yang kita ketahui sebagai media dakwah Muhammadiyah adalah bidang politik, bidang pendidikan dan bidang social namun tak banyak dari kita yang mengetahui bahwa Muhammadiyah juga bergerak di bidang kebudayaan dan kesenian dalam usahanya menyampaikan dakwah dan pesan dakwah, salah satu contohnya adalah pada karya seni khas nusantara yaitu kain batik dimana Muhammadiyah memiliki ciri sendiri pada motif batiknya dan telah memasarkannya secara umum melalui toko suara Muhammadiyah. Ini membuktikan bahwa organisasi keagamaan ini terbuka untuk segala jenis keberagaman.

Peneliti bermaksud untuk mengetahui hal tersebut dari kalangan muda, apakah sama persis seperti para gurunya atau mereka memiliki hal lain yang mempengaruhi nantiny

Maka peneliti memutuskan untuk meneliti hal tersebut. Menjadikan Organisasi Otonom Muhammadiyah "IMM" sebagai objeknya sebab.

Seperti pada penelitian skripsi sebelumnya yang berjudul Pesan-pesan Dakwah dalam Lagu-lagu Nasyid Group Nasyid Shaff-Fix (Studi Analisis Isi Pesan Dakwah dalam Album K'She). Penelitian ini berkaitan dengan pesan dakwah yang hendak disampakan group Nasyid Shaff-Fix pada pendegarnya lewat lagu-lagu mereka.

Pada penelitian ini penulis berupaya mencari tahu seperti apa pandangan Organisasi keagamaan Muhammadiyah terkait music yang dijadikan media untuk berdakwah terlepas dari pro dan kontranya hal tersebut serta ingin mengetahui pula seperti apa pesan dakwah yang Sabyan Gambus siarkan dalam lagi-lagu mereka serta untuk mengetahui bagaimana pandangan Muhammadiyah terkhusus IMM terhadap kehadiran Sabyan Gambus yang belakangan ini ramai diperbincangkan dan menjadi trendseter tersendiri dalam music dan dakwah.

Dari latar belakang masalah tersebut dapat dirumuskan beberapa masalah dengan focus penelitian: Bagaimana pandangan Muhammadiyah terhadap music? Pesan dakwah yang terkandung dalam lagu Sabyan Gambus? Bagaimana pandnagan Organisasi Otonon Muhammadiyah "IMM" mengenai kehadiran lagu-lagu bertema Islami dari Sabyan Gambus?

Penelitian ini dilakukan terhadap badan Otonom Organisasi Muhammadiyah yang ada dikampus UIN Sunan Gunung Djati Bandung yaitu IMM ( Ikatan Mahasiswa Muhammadiyah). Mahasiswa yang tergabung dikomunitas ini adalah mereka yang memiliki keinginan untuk mepelajari ajaran Islam yang diwadahi 
oleh Muhammadiyah dan Ahmad Dahlan sebagai penuntunnanya. IMM "Ikatan Mahasiswa Muhammadiyah" cabang Bandung Timur sudah berdiri sejak tahun 1974 ketika nama UIN Sunan Gunung Djati masih bernama IAIN Sunan Gunung Djati. IMM cabang Bnadung Timur didirikan oleh Prof. Dadang Kahmad M.SI namun semapat fakum sekitar tahun 2012, 2013 dan 2015. Keberadaan Sekretariat IMM awalnya berada ditempat kostan Prof. Dadang Kahmad M.SI namun kini sudah memiliki tempat sendiri yang dapat memfasilitasi para anggotanya. Dipilihnya lokasi disekitaran UIN Sunan Gunung Djati Bandung yang diharapkan dapat dimanfaatkan dan bermanfaat bagi para anggota IMM yang berada di Sekretarian UIN Sunan Gunung Djati Bandung cabang IMM Bandung Barat

Penelitian ini menggunakan metode deskriptif. Dalam bukunya Moh. Nazir, $\mathrm{Ph}, \mathrm{d}$ dijelaskan bahwa metode deskriptif adalah suatu metode yang dalam meneliti status sekelompok manusia, suatu objek, suatu set kondisi, suatu system pemikiran, ataupun suatu kelas pristiwa pada masa sekarang. Tujuan dari pnelitian deskriptif ini adalahuntuk membuat deskriptif, gambaran, atau lukisan secara sistematis, factual dan actual mengenai fakta-fakta, sifat-sifat serta hubungan antara fenomena yang diselidiki (Nazir, 2011; 54). Serta dalam penelitian ini juga digunakan teori pandangan, pandangan adalah proses memandang individu terhadap objek yang akan melibatkan perasaan dan pandangannya dalam memberikan pandangan.

\section{LANDASAN TEORITIS}

Teori yang digunakan dalam landasan penelitian ini adalah teori yang berkaitan dengan media dakwah dengan menggunakan media musik. Dakwah secara bahasa etimologis merupakan suatu kata dari bahasa Arab dalam bentuk masdar. Kata dakwah berasal dari kata da'a, yad'u, da'watan yang berarti seruan panggilan, ajakan undangan atau do'a. menurut Abdul Aziz, secara etimologis kata dakwah berarti: memanggil; menyeru; menegaskan atau membela sesuatu; perbuatan atau perkataan untuk menarik manusia kepada sesuatu; dan memohon dan meminta, atau doa. Oleh karna itu, dalam kegiatannya ada proses mengajak, maka orang yang mengajak disebut da'I dan orang yang diajak disebut mad'u (Enjang dan Aliyudin, 2009: 1-4)

Dalam suatu keberhasilan kegiatan dakwah tidak akan terlepas dari rukun atau unsur-unsur yang harus ada dalam proses dakwah, yang satu sama lain saling berkaitan. Rumusan unsur-unsur dakwah tersebut didasarkan pada definisi Al-Quran sebaga sumber ilmu Dakwah.

Proses serta unsur-unsur yang terdapat pada tanzil Al-Quran menjadi isyarat sekaligus sayarat berlangsungnya proses dakwah yang simultan anatara unsur yang satu dan unsur yang lain. Menurut kajian ilmu Dakwah terdapat lima unsur 
dakwah, yaitu: Dai sebagai penyampai Dakwah; Maudhu al-Da'wah atau pesan dakwah; Wasillah al-Da'wah atau media dakwah; Uslub al-Da'wah atau metode dakwah; Mad'u atau objek dakwah. (Tata Sukaryat, 2015:22-23)

Pertama, Da'I (Pelaku Dakwah) Da'I adalah orang yang melaksanakan dakwah, baik melalui lisan, tulisan maupun perbuatan, yang dilakukan secara individu, kelompok, maupun organisasi atau lembaga (Muhammad Munir dan Wahyu Illahi, 2006:22) Da'I harus mengetahui cara meyampaikan dakwah tentang Allah, alam semesta, kehidupan dan apa yang dihadirkan dakwah untuk memberikan solusi terhadap problem yang dihadapi manusia serta metode yang dihadirkan menjadikan manusia secara prilaku dan pemikiran tidak melenceng (Mustafa Malaikah, 1997:18)

Kedua, Maudhu al-Da'wah (Pesan Dakwah) Pesan dakwah adalah pesanpesan yang berupa ajaran Islam atau segala sesuatu yang harus disampaikan subjek kepada objek dakwah, yaitu keseluruhan ajaran Islam yang ada di dalam kitabulah dan sunah Rasulullah (Hafi Anshari, 1993: 140).

Ketiga, Wasillah al-Da'wah (Media Dakwah) Secara bahasa wasilah berasal dari bahasa arab yang berarti: al-wuslah, al-ittisaal yaitu segala hal yang dapat mengantarkan tercapainya kepada sesuatu yang dimaksud. Menurut Ibn Manzhur, al-wasilah, bentuk jamaknya: al-Wasalu dan al-Wasailu yang berarti singgasana raja, derajat atau dekat. Sedangkan artinya secara istilah adalah segala sesuatu yang dapat mendekatkan kepada suatu lainya. Alat yang digunakan sebagai perantara untuk melaksanakan kegiatan dakwah diantaranya berupa: lisan, tulisan, visual, audio dan keteladanan.

Keempat, Uslub al-Da'wah (Metode Dakwah). Secara bahasa, kata metode dalam bahasa latin berasal dari dua akar kata, yaitu meta yang berarti melalui dan hodos yang berarti jalan atau cara. Dalam bahasa Yunani, metode berasal dari kata methodos yang berarti jalan. Dalam bahasa bahasa Arab, metode disebut tariq atau tariqah yang berarti jalan atau cara. Kata-kata tersebut identic dengan kata al-Ualub. Secara perinci, metode dapat diartikan sebagai suatu cara yang bisa ditempuh atau cara yang ditentukan secara jelas untuk mencapai dan menyelesaikan suatu tujuan, rencana, system, tata pikir manusia (M. Syafaat Habib, 1992:160).

Kelima, Mad'u (Objek Dakwah). Mad'u atau sasaran (objek) dakwah. Objek dakwah yang diajak kepada Allah atau menuju al-Islam. Karena Islam bersifat universal, objek dakwah pun adalah manusia secara universal. Hal ini didasarkan juga kepada misi Muhammad Saw. yang diutus oleh Allah untuk mendakwahkan Islam kepada umat manusia.

Media berasal dari bahasa Latin yaitu medius yang secara harfiah berarti perantara, tengah atau pengantar. Dalam bahasa inggris media bentuk dari medium yang berarti tengah, anatara, rata-rata (Ali Aziz, 2004:403). Wilbur Schraman mendefinisiskan media sebagai teknologi informasi yang dapat 
digunakan dalam pengajaran. Secara spesifik, yang dimaksud dengan media adalah alat-alat fisik yang menjelaskan isi pesan atau pengajaran, seperti buku, film, video, kaset, slide dan sebagainya.

Adapun yang dimaksud dengan media dakwah adalah "alat yang yang dipergunakan untuk menyampaikan materi dakwah kepada mad'u" (Wahidin Saputra, 2012:288).

Media merupakan alat untuk menyampaikan pesan dakwah dari komunikator (Da'i) kepada komunikan (Mad'u). "Media dakwah adalah peralatan yang dipergunakan untuk menyampaikan materi dakwah, seperti radio, televisi, video, kaset, majalah, suratkabar" (Dulwahab, Encep; 2016)

Segala sesuatu yang digunakan untuk menyampaikan suatu tujuan tertentu maka itu adalah media. Adapun dakwah, dakwah adalah alat yang digunakan untuk menyampaikan tujuan atau materi dakwah, yang dapat berupa orang (tokoh) tempat, kondisi tertentu dan lainnya (Asmuni Syukir, 1983:63).

Berbicara tentang music itu artinya kita berbicara tentang tiga aspek yang melengkapinya yaitu melodi, ritme dan harmoni yang kesemuanya itu berasal dari suara. Sedangkan menurut Eya Grimonia penulis buku "Dunia Musik SainMusik untuk kebaikan hidup" menyatakan bahwa "Music adalah sesuatu yang sangat berpengaruh bagi kehidupan manusia. music sangat berpengaruh terhadap kehidupan manusia baik secara positive maupun negative. Kedua penagruh tersebut ditentukan oleh bgaimana kita menyikapi music yang kita rasakan, dan kita dengarkan sehari-hari"

Menurut beberapa pakar seperti Plato, Aristoteles, Imam Ghozali bahkan Maulana Jalaludin Rumi cukup berpengarus bagi kehidupan jiwa seseorang karna jika seseorang mendengarkan music yang baik, maka jiwanya akan menyerap yang baik. Demikian sebaliknya, music dapat memberi gairah dalam hidup beragama dan mendekatkan diri kepada sang Khaliq.

Music merupakan bahasa yang universal yang menjadi media komunikasi antarmasyarakat berbeda budaya. Music identic dengan bahasa bunyi yang berarti bahasa makna maka pendenganr akan bisa sangat terpengaruh olehnya apabbila ia telah mampu mamahami pesan dan makna di balik suasana atau irama music tertentu.

Musik berasal dari bahasa Yunani, asal katanya dari mousike yang diambil dari nama dewa yaitu mousa yang berarti pemimpin seni dan ilmu. Maka tak heran bila musik didefinisikan sebagai sebuah ungkapan dari perasan dan pikiran yang teratur dalam bentuk bunyi.

Dari definisi diatas,dapat diketahui bahwa, "Musik dapat menciptakan sebuah lagu. Sebuah lagu yang dinyayikan biasanya terdiri dari tiga komponen yang saling melengkapi dan saling bergantung” (Islami, Syifa H; 2016) 
Music sebagai media penyampai pesan dakwah bukanlah hal yang baru di Indonesia, bahakn jauh sebelumnya sudah dilakukan oleh para wali di tanah jawa menyebarkan agama islam dengan menggunakan instrument music gamelan yang dipandang sama pentingnya dengan dakwah itu sendiri. Oleh karna itu, perawatan benda-benda musical tadi senantiasa dilakukan dengan ssangat penuh perhatian.

Musik merupakan naluri manusia sejak dilahirkan. Allah Swt. telah membekali manusia dengan dua belahan otak, yaitu otak kanan dan otak kiri. Otak kanan berhubungan dengan fungsi intuisi sedangkan otak kiri berhubungan dnegan fungsi berfikir.

Menurut Deddy Mulyana M.A dalam bukynya "Nuansa-nuansa Komunikasi" menyebutkan bahwa ada syarat-syarat tertentu dalam bernyanyi, yaitu: Pesan dalam lagu tidak bertentangan dalam Islam. Meskipun pesan lagunya tidak haram, bila lagunya diiringi dengan gerakan-gerakan seksual yang sangat sugestif, maka nyanyiannyapun menjadi haram. Islam menentang segala hal yang berlebihan, bahkan juga dalam ibadah apalagi dalam hiburan. Keberlebihan itu pastilah mengorbankan kewajiban lain. Setiap orang adalah hakim yang baik, bila suatu jenis nyanyian membawa kdalam dosa, ia harus menghidarinya, jadi menutup pintu kedalam godaan. Ada kesepakatan bila cara bernyanyi (pakaian, penampilan, prilaku) dan kata-kata lagunya sendiri bertentangan dengan Islam, maka nyanyian itupun menjadi terlarang (Dedi Mulyana, 1999: 57).

\section{HASIL DAN PEMBAHASAN}

Penelitian ini dilaukan pada sebuah Organisasi Kemahasiswaan yakni IMM "Ikatan Mahasiswa Muhammadiyah" Organisasi ini berdiri di Yogyakarta pada tanggal 14 maret 1964 M / 29 syawal 1384 H. Tujuan IMM adalah "mengusahakan terbentuknya Akademisi Islam yang Berakhlak Mulia dalam rangka mencapai Tujuan Muhammadiyah". Dipilihnya lokasi disekitaran UIN Sunan Gunung Djati Bandung yang diharapkan dapat dimanfaatkan dan bermanfaat bagi para anggota IMM yang berada di Sekretarian UIN Sunan Gunung Djati Bandung cabang IMM Bandung Barat.

\section{Pandangan Muhammadiyah terhadap Musik}

Berdasarkan hasil penelitian yang dilakukan pada tanggal 02 April 2019, berdasarkan hasil wawancara kepada salah satu anggota IMM yakni M. Aziz Dikri yang menjabat sebagai Sekertaris Umum IMM Cabang Bandung Timur, bahwasanya pandangan mereka terhadap music sebagai demikian. 
"musik adalah sesuatu yang Mubah. Maksudnya adalah ketika music itu bermanfaat untuk kehidupan umat maka hal itu menjadi boleh bahkan hingga menjadi wajib dengan alasan menjadi jalan satu-satunya untuk masuk Islam, namun ketika music itu justru membuat kita menyimpang dari kebenaran yang sesuai dengan apa yang diperintahkan Allah SW'T., yang dilakukan oleh Nabi Muhammad dan yang dipraktikan oleh para sahabat maka itu dapat dikatan haram".

Muhammadiyah sendiri dalam hal berdakwah dengan menggunakan music sebagai salah satu alatnya sebenarnya telah dicontohkan oleh Ahmad Dahlan ketika ia berupaya menyiarkan Agama Islam di Tanah jawa setelah ia pulang dari Mekah, beliau menyebarkan dakwah dengan syair-syair yang diiringi alat music biola.

Muhammadiyah sendiri khususnya IMM memandang music adalah sesuatu yang mubah tapi tidak pula menghalalkan ataupun mengahramkan, hukumnya ada dipertengahan, hukumnya terletak pada illatnya atau pada sebab akibatnya. Jika membuat sesorang menjadi baik maka baik pula hal tersebut namun jika menjadi sebaliknya maka music tesebut bisa diharamkan kegunaan dan pemanfaatannya.

Hal tersebut sejalan dengan pendapat dari Masyfuk Zuhdi bahwa "music dan nyanyian itu termasuk ke dalam kategori dzarah yang dasar hukumnya mubah dan mengandung unsur positifnya lebih besar daripada unsur negatifnya". Karna itu, music dan nyanyian itu pada dasrnya mubah (boleh), bahkan hukumnya bisa meningkat menjadi sunah atau wajib, tergantung pada keadaan tingkat masalahnya (Aripudin, Acep. 2012).

Musik adalah sebuah media yang manfaat dan kegunaannya tergantung pada kita yang menggunakannya, jika kegunaanya untuk kebaikan contohnya untuk menysiarkan agama Islam maka hukumnya boleh atau diperbolehkan bahkan seperti yang dikatakan oleh sodara M. Azis Zikri sebagai Sekertaris Umum cabang Bandung timur bahwasanya music dapat dikatakan halal dan mewajibkan jika itu menjadi salah satu cara untuk mengenal agama Islam dan untuk memperdalamnya.

Menurut Rafi Tajdidul Haq salah satu anggota muda IMM mengatakan bahwa "ada tiga gerakan dakwah yang ada dibawah lingkup Muhammadiyah, yakni gerakan dakwah kebangsan, gerakan dakwah jamaah dan gerakan dakwah cultural dan dalam pembahsan ini dakwah cultural-lah yang relevan"

Dari segi keagmaan dan kemasyarakatan hal ini menaruh pengaruh yang besar yakni dalam segi agama bahwa proses menyebarkan agama tidak melulu dengan kegiatan ceramah dari satu mimbar ke mimbar yang lain namun dapat dilakukan dengan music sebgai mana kita ketahui bahwa music adalah sesuatu 
yang dekat dengan kita dan sangat bersahabat dengan kita, dan dari segi kemasyarakatan music sebagai media hiburan (entertainment) juga dapat dijadikan sebuah media penyampain ajaran keislaman yang ringan dan cepat ditanggapi oleh para pendnegarnya (masyarakat) sedangkan dari sisi kemahasiswaannya ini membuka pemahaman baru terkait dakwah dan media untuk berdakwah, menjadi lebih terbuka pada sesuatu yang baru meskipun seperti yang sering penulis ulangi bahwasanya music sudah sejak dulu dijadikan media untuk berdakwah hanya saja lebih sering disebut atau lebih dikenal dengan syair.

Menurut Sodara Ilyasa Waliyudin Shidiq yang merupakan ketua bidang Organisasi IMM cabang Bandung Timur ini, kehidupan tanpa music itu hampa dan tidak bermakna tidak bisa dipungkiri bahwa music itu dekat dengan kita setidak-tidaknya dalam Adzan saja ada nada yang merupakan bagian dari music itu sendiri serta dalam berbicara saja kita menggunakan music atau yang lebih kita kenal dengan istilah intonasi, bayangkan jika dalam berbicara tidak ada intonasi yang mengiringinya maka akan banyak terjadi kesalah pahaman, intonasi itu penting dalam sebuah dialog atau percakapan, kita dapat mengetahui orang itu marah, sedih senang kecewa dan lainnya dari intonasi itu sendiri bukan saja dari kata dan pembendaharaan katanya.

Sementara itu menurur M. Quraish Sihab dalam bukunya yang berjudul Fatwa-fatwa Seputar Wawasan Agama menyatakan bahwa

"tidak ada larangan lagu (music) di dalm Islam. Bukankah ketika Nabi Saw., pertama kali tiba dimadinah beliau disambut dengan nyanyian. Ketika perkawinan, Nabi juga merestui nyanyian yang menggambarkan kegembiraan. Yang terlarang adalah mengucapkan kalimat-kalimat, baik ketika menyanyi ataupun berbicara yang mengandung makna-makna yang tidak sejalan dengan ajaran Islam"

Dari pendapat diatas kita dapat mengartikan bahwa bukan pada media (music) yang dipersalahkan tapi pada apa yang disampaikan. Lagu dari Ebit G. Ade yang berjudul Berita Kepada Kawan yang menceritakan tentang tanah yang dirusak oleh tangan tidak bertanggung jawab sebagian manusia yang menyebabkan kerusakan dan penderitaan manusia lainnya seharusnya dapat menjadi pembelajaran untuk kita, lagu yang syarat akan makna dan pesan moral dari kehidupan ini seharusnya dapat menyadarkan kita akan tanggung jawab kita sebagai ' Khalifah fil Ar-rad". Ebit mengemas pesan tersebut pada sebuah media yang dekat dengan kita yaitu music yang diharapkan dapat menyadarkan kita lewat syair-syairnya.

Dan lagu El Touna Tufuli yang pernah juga dicover oleh Sabyan Gambus yang mana menceritakan tentang penderitaan warga Palestina terlebih derita yang dialami oleh anak-anaknya, mereka menentang dan mempertanyakan tentang keadilan yang seharusnya ada dan melindungi mereka lebihnya pada 
mereka yang menyatakan dirinya mampu untuk memberi perlindungan pada siapapun tanpa terkecuali.

Barulah lagu-lagu seperti It Will Rain dari Brono Mars, dalam liriknya "There's no religion that could save me" yang bila diartikan "tidak agama yang dapat menyelamatkan saya" lirik lagu ini sama halnya dengan ajakan dan seruan untuk berpaling dari ajaran agama dan Tuhan (Murtad).

\section{Pesan dakwah yang terkandung dalam lagu Sabyan Gambus}

Pertama. dalam lagu yang berjudul Ya Maulana merupakan intisari dari Surat AlIkhlas yang mana berserah diri dan kembali pada Allah SWT., mengambarkan sebuah kecintaan seorang hamba pada Allah SWT., jika dikaji dalam ilmu Tasawuf ini termasuk pada kategori atau maqomat Mahabah kecintaan pada Allah SWT, hal ini dikemukankan oleh sodara Rexsa Sandi Purnama anggota muda IMM. Mahabah adalah kecintaan yang melebihi rasa cinta pada apapun, mempercayai bahwa dengan bergantung pada Allah SWR., kehidupannya sudah terjamin dan tak ada unsur keduaniawian yang meliputi hatinya. Menurut Rexsa Sandi Purnama salah satu anggota muda IMM mengtakan bahwa "dalam lagu ini menggambarkan tentang kecintaan seorang hamba pada Allah SWT dimana ini dikaji dalam ilmu tasawuf pada bahasan mahabah yang artinya adalah kecintaan, kecintaan pada Allah SWT., melebihi apapun”. Pada lagu yang berjudul "Ya Maulana" yang menceritakan tentang ungkapan rasa syukur dan permohonan pada Allah SW'T.

Dalam lagu ini kita diingatkan bahwa seberapa banyak dosa yang kita telah lakukan rahmat dan karunia Allah SWT masih menyertai kita dan yang terpenting adalah bahwa segala yang Allah SWT beri tidak dapat digantikan oleh apapun tidak dapat terbalaskan oleh apapun sehingga disini permohonan maaf atas perilaku yang buruk yang disengaja atau tidak harus dipanjatkan. Lagu ini mengajarkan pada kita untuk selalu menginstrofeksi diri dan memperbaiki diri.

Dalam lafad Basmallah terdapat kalimat Rahman dan Rahim yang bila diartikan adalah kenikmatan, karunia dan kasih sayang tapi yang membedakan adalah pada objeknya, jika Rahman adalah kasih sayang untuk seluruh umat didunia tanpa terkecuali maka dalah kalimat Rahim, untuk mereka yang memenangkan syurga sebagai balasan dari apa yang telah ia lakukan semasa hidupnya, kesih sayang itu sebatas pada umat-umat yang berlaku taat semasa hidup didunia yang tak pernah berpaling, menduakan dan mendustakan agamaNya.

Permohonan maaf ini untuk siapa saja tak terlepas dari siapa dan seperti apa mereka, yang membedakan manusia dengan manusia lainnya adalah ketaatannya bukan harta tahta dan rupanya. Manusia adalah tempatnya salah, ini maklum sebab manusia adalah insan yang mana dekat dengan lupa dan hilap 
untuk itu permohonan maaf dan meminta ampunan ini harus selalu didawamkan dalam hati, sengaja atau tidak mungkin kita pernah melakukan sebuah dosa maka selagi dapat bernapas dan dapat meminta permohonan maaf panjatkanlah sebab Allah SWT selalu memberi ampunan yang luas dan taubat yang sebesarbesarnya dapat dilakukan siapa saja sebelum nyawa diambil dan telah sampai dikerongkongan.

Lagu "Ya Maulana" bila dikaji lagi didalamnya terdapat inti sari dari surat Al-Ikhlas yaitu berserah diri dan kembali lagi pada Allah SWT., menggambarkan sebuah kecintaan seorang umat pada Allah SW'T., yang bila diperdalam lagi ini termasuk pada Mahabbah yang dikaji dalam ilmu tasawuf, dimana menurut Harun Nasution, Mahabbah adalah kecintaan seorang umat pada Allah SW'T., yang diantaranya adalah memeluk ketaatan pada Allah dan membenci segala sikap yang melawan pada-Nya, menyerahkan seluruh diri pada yang dikasihi, mengosongkan hati dari segala-galanya kecuali dari yang dikasihi yaitu Allah SWT., artinya adalah taat pada segala yang diperintahkan Allah SWT., dan menjauhi segala apa yang dilarang Allah SWT., menyerahkan segala hidup dan matiny hanya pada Allah SWT., tentang apapun yang Allah SWT., kehendaki atas dirinya dan hanya mencintai Allah SWT., lebih dari segalanya dalam hatinya hanya ada Allah SWT., tanpa terkecuali.

Dan bagi penulis lagu "Ya Maulana" ini secara garis besar menyiratkan hal itu pada para pendengarnya, salah satu bentuk dakwah dengan media yang $\mathrm{t}$ erkesan "kekinian" meski tidak dapat dipungkiri bahwa untuk dakwah seperti ini sudah ada sejak zaman para Nabi namun umumnya lebih dikenal dengan syair, dan hal ini menjadi sarana yang membantu yang dapat dilakukan dizaman modern ini.

Kedua, Pada lagu kedua Sabyan Gambus yaitu "Allahumalabaikh" terdapat rukun Islam yang ke lima yaitu menunaikan ibadaha haji ketanah suci dimana ibadah ini sudah ada sejak nabi Ibrahim hidup. Lagu ini menceritakan tentang sebuah perjalanan umat untuk menemui Allah SWT., ditanah suci, menceritakan suka duka dan harapan-harapan yang telah ada sejak lama untuk menunaikan ibadah ditanah yang Allah SWT., cintai, tanah dimana Islam pertama kali didakwahkan atau disebarkan. Menurut Ilsaya Waliyudin Shidiq "lagu ini adalah ungkapan atas semua cita-cita umat Islam di Dunia yang mana harapan pergi ke tanah suci merupakan harapan terbesar seorang muslim dan betapa bahagianya bila dapat melaksanakannya, melaksanakan ibadah yang sedarri dulu telah dilakukan oleh para Nabi-nabi".

Menurut Ilsaya Waliyudin Shidiq "lagu ini adalah ungkapan atas semua cita-cita umat Islam di Dunia yang mana harapan pergi ke tanah suci merupakan harapan terbesar seorang muslim dan betapa bahagianya bila dapat melaksanakannya, melaksanakan ibadah yang sedarri dulu telah dilakukan oleh para Nabi-nabi" 
Lagu yang berjudul "Allahbuma Labaikh" ini menceritakan tentang keinginan terbesar seorang muslim untuk menunaikan ibadah ditanah suci, Mekah Al-Mukaromah. Tempat dimana dakwah Islam pertama kali dilakukan. Tuntunan mengerjakan ibadah haji ini ada sejak zaman Nabi Ibrohim As, yang mana Nabi Ibrahim As-lah yang pertama kali diperintahkah untuk melaksanakan ibadah haji oleh Allah SWT., namun seiring berjalannya waktu banyak umat yang tidak bertanggung jawab dalam praktik hajinya berpaling dari yang seharusnya, untuk itulah selanjutnya Allah SWT., memerintahkan Nabi Muhammad SWA untuk menyempurnakannya kembali.

Lagu ini menggambarkan tentang sebuah mimpi beribadah ditanah suci yang menjadi kenyataan, gambaran kebahagian seorang muslim karna dapat beribadah dan memenjatkan doa ditempat suci itu. Mengenal lebih dekat kekuasaan Allah SWT dengan sejarah-sejarah besar yang menyertai tempat itu, tempat dakwah pertama kali dilakukan dengan penuh perjuangan oleh Nabi Muhammad SWA yang hingga kini berkat perjuangannya nikmat iman dan islam dapat kita rasakan.Karna ibadah ini, adalah salah satu ibadah yang sudah turun temurun dilakukan dan diajarkan sejak zaman Nabi Ibrahim As.

Ketiga, El Oum menurut sodara M. Azis dikri "lagu ini memiliki makna yang begitu mendalam, berkaitan dengan Birrul Walidain yang merupakan ibadah yang paling mulia yang mana ibadah yang satu ini sangat dianjurkan oleh Rasulullah Saw, terutama bakti kita terhadap ibu". Lagu El Oum, menceritakan tentang sebuah bakti anak pada orang tuanya terutama pada sang ibu, meski ada atau telah tiada doa untuknya akan selalu terkumandangkan, sebab itu satusatunya usaha untuk membalas cinta mereka yang telah tercurahkan untuk kita dari awal dari dalam kandungan hingga sekarang. Lagu ini menggambarkan jelas bakti seorang anak pada orang tuanya.

Menurut M. Azis dikri "lagu ini memiliki makna yang begitu mendalam, berkaitan dengan Birrul Walidain yang merupakan ibadah yang paling mulia yang mana ibadah yang satu ini sangat dianjurkan oleh Rasulullah Saw, terutama bakti kita terhadap ibu" Single ketiga dari Sabyan Gambus ini menceritakan tentang kisah kehilangan yang dialami seorang anak namun dalam kehilangan dan ketidak tahuannya itu ia selalu berdoa untuk kebaikan orang tuanya.

Ridho Allah SWT tergantung pada ridho orang tua, inilah keagungan orang tua yang Allah berikan. Adalah kewajiban kita untuk mendoakan orang tua baik yang masih ada maupun sudah tiada sebab sampai kapanpun semua jasa-jasa orang tua tidak akan pernah bisa terbalaskan.

Birrul Walidain, merupaka salah satu etika dalam Islam yang didalmnya menunjukan perbuatan dan tindakan bakti kepada kedua orang tua kita. Hokum dari berbakti pada orang tua ini adalah fardu ain tidak memandang pada siapa dan seperi apa mereka, sekalipun kedua orang tua kita adalah non muslim. 
Dalam Islam berbakti dan menghormati tidak hanya pada orang tua saja, keuniversalannya mencangkup pada berbakti dan menghormati orang yang lebih tua dari kita dan sebaliknya yang lebi tua harus menyayangi yang lebih muda.

Pengorbanan orang tua yang amat begitu besar dan rasa hormat serta bakti kita sebenarnya belum cukup untuk membalas semua jasa-jasa dari mereka maka karna hal tersebut seharusnya membuat kita sadar dan malu bukan berbuat sebaliknya.

Perbuatan hormat dan bakti pada orang tua telah dilakukan dan ditunjukan oleh para Nabi dan para sahabat, kisah bakti anka terhadap orang tuanya terutama terhadap ibu yang sangat mendunia adalah kisah dari Uwais AlQorni yang namanya tidak dikenal didunia semasa itu namun begitu dikenal oleh penduduk langit dari dulu hingga sekarang, perbuatan baktinyalah yang membuat hal itu terjadi, seperti yang dikatakan oleh Umar bin Khatab dalam sebuah riwayat yang mengatakan bahwa "saya mendengar Rasulullah SAW, bersabda "Uwais bin Amir akan datang bersama rombongan orang dari Yaman dahulu tinggal di Murrad kemudia tinggal di daerah Qarn. Dahulu dia pernah terkena penyakit belang, lalu sembuh, akan tetapi masih ada belang di tubuhnya sbersar uang dirham. Dia memiliki seorang Ibu, dan dia sangat berbakti pada ibunya. Seandainya dia berdoa kepada Allah, pasti Allah akan mengabulkan doanya. Jika engkau bisa meminta kepadanya agar memohonkan ampunan untukku pada Allah maka usahakanlah" dan Uwais-pun memintaka ampunan untuk Umar bin Khatab pada Allah SWT (Hadist Riwayat Muslim). Terlihat begitu jelas bahwasanya sebuah bakti yang dilakukannya dapat membuat dirinya dekat dengan Allah SW'T hingga apaun yang ia minta Allah SWT., senantiasa mengabulkannya.

Bakti kepada orang tua adalah suatu ibadaha yang paling mulia, yang dengan melakukannya dapat membuat dosa-dosa terampuni, dapat mengantarkan kita pada surge yang telah Allah SWT janjikan dan sediakan untuk orang-orang yang bertaqwa, Allah SWT ridho bila kedua orang tua kita juga meridhoinya, keberkahan rejeki dan mumbuat panjang umur. Namun terlepas dari hal-hal itu, berbakti kepada kedua orang tua adalah sebuah hak yang harus diperoleh oleh kedua orang tua kita seperti arti tersendiri dari kata Al-Birr yang artinya adalah baiknya ahlak, yang merupakan hak dari kedua orang tua dan kerabat dekat. Dan merupakan kewajiban untuk seorang anak, namun ketika sudah mengetahui sebab ia harus berbakti kepada kedua orang tuanya maka bisa saja menjadi sebuah kebutuhan dan keharusan.

Dari semua penjabaran tentang Birrul Walidain atau bakti kepada kedua orang tua yang ada dibagian atas maka dalam lagu "El Oum" ini menjadi pengingat kembali untuk kita bahwasanya berbakti kepada orang tua adalah hal yang sangat wajid dilakukan dan mendoakan orang tua adalah upaya terkecil untuk menyenangkan dan membalas jasa-jasa orang tua kita. 
Keempat, Menurut sodara Ilyasa Waliyudin Shidiq "lagu syukronlillah ini adalah bentuk dari kedewasaan diri, yang mana ketika satu hal yang kita ingini belum terkabul dan kita tidak berputus dari Rahmat Allah SWT., merupakan sebuah perilaku kedewasaan diri dari kta". Lagu Syukronlillah yang merupakan lagu keempat dari mereka ini kehadirannya memang begitu cepat diterima oleh para penikmat music tanah air. Lagu yang menceritakan tentang sebuah rasa syukurseorang umat atas nikmat yang Allah SWT., mengajarkan kita untuk selalu bersyukur atas segala yang Allah SWT., beri meski pemberian tersebut tidak sesuai apa yang kita mau, disini kita harus ingat semua sekenario yang Allah SWT telah buat untuk umatnya adalah yang terbaik dari semua hal yang baik, Allah SWT lebih mengetahui umatnya dari pada umatnya itu sendiri tentng apa yang akan terjadi padanya, maka mensyukuri segala nikmat Allah SWT adalah hal yang harus senantiasa ditanamkan dalam jiwa.

Menurut sodara Ilyasa Waliyudin Shidiq "lagu syukronlillah ini adalah bentuk dari kedewasaan diri, yang mana ketika satu hal yang kita ingini belum terkabul dan kita tidak berputus dari Rahmat Allah SWT., merupakan sebuah perilaku kedewasaan diri dari kta".

Lagu terbaru dari Sabyan Gambus yang berjudul "Syukronlillah" ini menceritakan tentang bentuk rasa syukur seorang umat kepada Allah SWT yang maha memberi. Sebagaimana firman Allah SWT., dalam surat Ibrahim ayat tujuh, yang artinya " Dan ketika Tuhanmu memaklumkan: sesungguhnya jika kamu bersyukur, pasti kami akan menambah (nikmat) kepadamu, dan jika kamu mengingkari (nikmat-Ku) sesungguhnya azab-Ku sangat pedih".

Sekecil apapun yang Allah Beri semestinya harus tetap kita syukuri, apapun yang Allah beri terlepas dari keinginan kita atau bukan harus tetap kita syukuri, Allah lebih tau apa yang terbaik untuk umat-Nya dibandingkan umat itu sendiri.

Ujian dan cobaan yang Allah beri bukan sebagi bentuk dari ketidak pedulian Allah pada umat-Nya, justru sebaliknya, saat-saat itulah Allah sedang mengistimewakan kita, bahwasanya Allah SWT., sedang memperhatikan kita dan sedang mempercayai kita bahwa kita adalah salah satu dari sekian banyak umat manusia yang begitu kuat tangguh dan tegar dalam mengahdapi segala cobaan dan ujian. Analoginya, ketika kita hendak naik pada level atau kelas tertinggi yang lebih tinggi dari yang sekarang kita duduki maka kita harus melalui sebuah ujian dulu dan setelahnya maka kita dapat dinyatakan lulus atau tidak, dinyatakan berhsil atau sebaliknya. Berputus asa akan Rahmat Allah sama dengan tidak mempercayai bahwa Allah itu maha agung dan maha besar.

\section{Pandangan Organisasi Otonom Muhammadiyah IMM mengenai kehadiran lagu-lagu bertema Islami dari Sabyan Gambus}


Pada penelitian bagian ini membahas tentang bagiamana pandangan IMM terhadap hadirnya Sabyan Gambus dalam blantika music Indonesia. IMM sendiri sebagian besar menyukai dan memberi respond positif terhadap kehadiran Sabyan Gambus dibelantika music tanah air yang dimulai dari tahun lalu ini, dimana mengakuai bahwa peranan anak muda atau kontribusi anak muda dalam siar Islam begitu besar dan sangat vital. M. Azis Dikri mengatakan bahwa "dakwah dengan media music akan menjadi wajib apabila menjadi salah satu atau hanya satu-satunya jalan untuk menemukan Islam"

"Kecenderungan anak muda sekarang dengan segala hal yang mudah kadang menyelitkan atau menghambat mereka untuk mempelajari agama namun dengan mendengarkan music yang memiliki makna-makna ajaran keislaman setidaknya mampu untuk mengisi kebutuhan ajaran Islami, dengan media yang ringan ini dakwah secara perlahan akan mudah diterima" (Rexsa Sandi Purnama, Selasa 04 April 2019).

Berdakwah seyogyanya tidak lagi dari satu mimbar ke mimbar lainnya atau maksudnya adalah dari satu majelis kemajelis lainnya dengan keadaan yang seperti sekarang ini dakwah bisa dilakukan dengan cara apa saja salah satunya dengan music, sebab music adalah salah satu hal yang san gat dekat dengan kita dizaman sekarang ini, pemamnfaatannya bisa menunjang kemaslahatan.

Sabyan Gambus melakuan dakwah dengan media music adalah sebuah terobosan yang dapat diperhitungkan keberadaannya. Meski bukan hal yang baru sebab sudah dicontohkan oleh Para Nabi dan Sahabat pada zamannya, yang lebih dikenal dengan istilah "syair" namun dakwah melalui music ini menjadi terobosan baru dalam berdakwah. Hari ini tidak dapat dipungkiri lagi bahwa kehadiran music begitu dekat dengan kita. Industry music tanah air yang pesat dalam perkembangannya mempengaruhi terhadap pola tingkah laku masyarakatnya, bahkan music sudah menjadi kebutuhan seseorang, baik dari segi hiburan, mata pencaharian dan lainnya.

Sebagai mana yang dikatakan oleh M. Faris Rasyadan bahwa "music selain untuk hiburan dapat digunakan untuk berdakwah, sebab kehadirannya dan keberadaanya itu amat dekat dengan kita terkhusus untuk anak mudanya dan apa yang dilakukan Sabyan Gambus terhadap dakwah dan music adalah suatu hal yang cerdas".

Untuk generasi muda, masa-masa sekarang ini harus digunakan dengan seproduktif mungkin dalam hal kebaikan, seperti contohnya dalam berdakwah sebaba dakwah adalah sebuah kewajiban utnuk setiap umat Nabi Saw. apa yang dilakukan para musisi tanah air ataupun manca Negara dalam hal ini patutlah untuk diapresiasi sebab dengan adanya mereka menanbah khazanah dalah penyiaran dakwah.

Menurut sodara M. Azis Dikri "Sabyan Gambus kehadiarannya telah merubah prilaku anak mudanya dalam hal kegemaran pada suatu genre music". 
Bagaimana tidak, axistensi mereka telah mempengaruhi sebagian besar masyarakat Indonesia dalam hal bermusik, kegemaran terhadap music tidak lagi hanya sebtasa pada apa-apa yang diproduksi negri barat semata namun negri dari timur juga.

Jika biasanya genre music tanah air dipenuhi oleh genre Pop, Jazz, Metal, Rock hari ini bertambah dengan adanuya Sabyan Gambus, ada genre khas timur tengah (gambus) dalam ragam music Indonesia. Tidak dapat dipungkiri lagi bahwa kepopuleran mereka bukan hanya di tanah air saja namun sudah disebagian Asia ini dan ini menunjukan bahwa meeka dapat meyiarkan dakwah Islam lebih luas lahi.

Menurut sodara Ilyasa Waliyudin Shidiq “ Sabyan Gambus ini telah memanfaatkan dengan baik media music sebagi sarana untuk menyiarkan agama Islam". media pada dasarnya hanyalah boneka yang dapat diperlakukan sesuai keinginan pemiliknya, bila untuk kebaikan maka akan menimbulkan atau menghasilkan kebaikan pula dan sebaliknya. Keberadaan music sendiri untuk Sabyan Gambus nampaknya digunakan selain sebagai media hiburan juga media siar Islam yang sangat membantu dakwah di Indonesia ini.

Sebagaimana pendapat sodara Ilyasa diatas, beliau berpendapat lagi bahwa "tontonan yang dapat menuntun adalah hal positif yang dapat diambil dari media hiburan itu sendiri, seperti yang Sabyan Gambus lakukan" sama seperti pendapat yang telah dijelaskan dari penelitian sebelumnnya bahwa pertunjukkan sebuah seni tidak hanya sebagai ungkapan seni semata, tetapi pertunjukkan sebuah seni harus difungsikan sebagai sarana penyebaran agama, dalam konteks ini adalah Islam (Nurhidayah, Yahya; 2017)

Keberadaan Sabyan Gambus dilihat dari dua sudut pandang yakni sudut pandang pengiat dan penikmat. Dari sudut pandangan penggiat merupakan bentuk kepedulian terhadap masyarakat yang mana sudah bertahun-tahun selalu disuguhi music-musik yang tidak memiliki pesan-peasn untuk sebuah kebaikan dan dari sisi penikmat dari sekian banyak lagu-lagu yang ada di tanah air setidaknya ada beberapa lagu yang pean-pesannya dapat diambil, mengurahi beberapa persen hal buruk yang akan terjadi yang diakibatkan oleh pesan-pesan buruk itu, yang mana suatu pesan jika diperdengarkan berkali-kali akan tersimpan dengan sendirinya dialam bawah sadar si pendengar, pendapat diatas sejalan dengan pribahasa dari tanah Sunda yakni "cikaracak ninggang batu launlaun jadi legok".

Menurut sodara Rafi Tajdidul Haq "Sabyan Gambus dalam pengaplikasian music pada dakwah ini sejalan dengan gerakan dakwah "IMM" pada lingkup budaya yang sangat relevan dengan bahasan music sebagai media dakwah”. 
Muhammadiyah secara luas dalam dakwah dan budaya memiliki andil tersendiri didalamnya, dan seperti apa yang sodara Bramayi katakana, bahwa "Ahmad Dahlan sepulang dari Mekah menyebarkan dakwah lewat syair yang diiringi oleh instrument music biola".

Menurut sodara Syukron Abdilah " hal yang cerdas menggunakan music untuk kegiatan berdakwah, jangan haramkan meidanya tapi pesannya dan yang dilakukan Sabyan Gambus bukan sesuatu yang haram, bukankah sudah dilakukan juga oleh orang Sholeh sebelum kita!" pendapat dari beliau ini sejalan dengan pendapat dari M. Quray Sihab,

"tidak ada larangan lagu (music) di dalm Islam. Bukankah ketika Nabi Saw., pertama kali tiba dimadinah beliau disambut dengan nyanyian. Ketika perkawinan, Nabi juga merestui nyanyian yang menggambarkan kegembiraan. Yang terlarang adalah mengucapkan kalimat-kalimat, baik ketika menyanyi ataupun berbicara yang mengandung makna-makna yang tidak sejalan dengan ajaran Islam"

Dari pendapat diatas dan dari jejak sejarah dapat ditarik kesimpulan bahwa memang music memiliki tempat penting dalam gerakan dakwah, dan jika melihat pada sejarah banyak pula Para Nabi, Sahabat dan orang-orang sholeh setelahnya yang menciptakan syair-syair untuk mengungkapkan rasa cintanya pada Allah SWT., dan lebihnya untuk siar Islam juga untuk bahan pelajaran, seperti yang terdapat pada beberapa kitab salafiyah yang mana kebanyakan diantaranya adalah syair-syair untuk mengiringi kegiatan belajar, contohnya kitab Aqidatul Awam, Tijandarori, Jurmiyah dan Alfiyah yang lekat dengan music ataupun lagu dan lebih dikenal dengan istilah "Nadhoman".

\section{PENUTUP}

Berdasarkan dari penelitian tentang music sebagai media dakwah yang memfokuskan penelitiannya pada: pandangan Muhamadiyah terhadap music, pesan dakwah yang terdapat pada lagu-lagu bertema Islami dari Sabyan Gambus dan juga tentang pandangan Organisasi Otonom muhammadiyah mengenai kehadiran lagu-lagu bertema Islami dari Sabyan Gambus.

Pandangan Muhammadiyah terhadap music bahwasanya bagi Muhammadiyah sendiri music adalah sesuatu yang diperbolehkan namun tidak pula dihalakan dan disarankan. Melihat dari kegunaannya music bisa dikatakan halal dan juga haram, bagaimana pemanfaatan dari penggunanya sendiri. Akan menjadi halal apabila itu menjadi jalan satu-satunya untuk menemukan atau mempelajari agama Islam namun akan menjadi haram bila dapat melalaikan kita atas kewajiban-kewajiban kita dalam beribadah pada Allah SWT., namun pada dasarnya music itu dihukumi sebagai sesuatu yang mubah (diperbolehkan)

Pesan Dakwah yang terkandung dalam Lagu Sabyan Gambus, diantaranya adalah: Pertama, Pesan Akidah pada lagu Sabyan Gambus terdapat pada lagu Ya 
Maulana yang menceritakan tentang suatu keimanan dan kecintaan umat terhadap pencipta-Nya; Kedua, Pesan Ahlak pada lagu Sabyan Gambus terdapat pada lagu El Oum yang menceritakan tentang bakti anak terhadap orang tuanya, Birrul Walidain. Dan terdapat dalam lagu syukronlillah yang menceritakan tentang kesadaran umat manusia akan rahmat Allah SWT dan berusaha untuk menerima segalanya entah yang baik, dinginkan ataupun tidak ;Ketiga, Pesan Syariah pada lagu Sabyan Gambus terdapat pada lagu Allahummalabaikh yang menceritakan tentang ibadah haji yang mana ibadah ini telah ada sejak zaman Nabu ibrohim As, yang telah banyak mengalami pembaharuan dan penyempurnaan terkait hal baik dan buruknya.

Pandangan Organisasi Otonom Muhammadiyah "IMM" mengenai lagulagu bertema Islam dari Sabyan Gambus. Berdasarkan dari wawancara yang telah dilakukan dapat disimpulkan bahwa "IMM" memandang Musik selain sebagai media entertainment juga sebagai media dakwah yang relevan untuk kondisi generasi muda saat ini dalam kaitannya sebagai media untuk berdakwah. Membuktikan bahwa siapa saja dapat menyiarkan ajaran agama Islam dengan media yang sangat dekat dengan kita atau lebih tepatnya telah bersahabat dengan kita.

Dalam penelitian ini, penulis berharap agar semakin terbuka lagi pemikiran masyarakat tentang sebuah media dakwah yang menggunakan music sebagai alatnya. Mengingat kegiatan ini sudah ada sejak zaman Rasulullah SAW dan yang mana music adalah alternative untuk mendakwahi generasi muda saat ini. penulis berharap agar khazanah ilmu dakwah juga membahas music dengan begitu terperinci lagi hingga kedepannya, tidak menimbulkan pro dan kontra didalamnnya dan juga dapat memudahkan peneliti-peneliti lain dalam menjadikan music sebagai bahan penelitian dan kajiannya. Penulis berharap agar music dapat mendapat titik terang atau kejelasan tentang hukumnya sendiri, tidak simpang siur lagi seperti saat sekarang ini.

\section{DAFTAR PUSTAKA}

Grimonia, E (2014), Dunia Musik Sains-Musik untuk Kebaikan Hidup, Bandung, Nuansa Cendekia

Nazir, M (2011), Metode Penelitian, Bogor, Ghalia Indonesia

Sukaryat, T (2015), Ilmu Dakwah, Bandung, Simbiosa Rekatama Media

Aliyudin, E, As (2009) Dasar-dasar Ilmu Dakwah, Bandung, Widya Padjajaran

Illahi, M, M dan Wahyu (2006), Manajemen Dakwah, Jakarta, Perdana Media

Aziz, M, A (2004) Ilmu Dakwah, Jakarta, Kencana

Syukri, A (1983) Dasar-dasar Strategi Dakwag Islam, Surabaya, Al-Ikhlas

Aripudin, A (2012) Dakwah Antar Budaya, Bandung, Remaja Rosda Karya

Malaikha, M (1997) Manhaj Dakwah Yusuf Qordhawi Harmoni Antara 
T. S. Wulandari, M, Aliyudin \& R. Dewi

Kelembutan dan Ketegasan, Jakarta, Pustaka Al-Kauthsar

Ashari, H (1993) Pemahaman dan Pengalaman Dakwah, Surabaya, Al-Ikhlas

Habib, M, S (1992) Buku Pedoman Dakwah, Jakarta, Wijaya

Mulyana, D (1999) Nuansa-nuansa Komunikasi, Bandung, Remaja Rosda Karya

Islami, S, H (2016) Pesan Dakwah dalam Lirik Lagu Ebiet G. Ad, Tabligh: Jurnal Komunikasi dan Penyiaran Islam. 1 (1). 108

Dulwahab, E (2016) Rebranding Dakwah di Media Televisi, ANIDA: Aktualisasi Nuansa Ilmu Dakwah. 15 (2). 304

Nurhidayah, Y (2017) Kesenian Tari Topeng sebagai Media Dakwah. Ilmu Dakwah: Academic Journal for Homelitic Studies.11 (01). 34 